\title{
Performance Evaluation of Small Engine Operated Sugarcane Harvester
}

\author{
Md. Tahsin Ashraf ${ }^{1}$, R. K. Naik ${ }^{2}$ and D. K. Roy ${ }^{3}$ \\ ${ }^{1}$ Department of Farm Machinery and Power Engineering, \\ IGKV, Raipur, Chhattisgarh, India \\ ${ }^{2}$ Department of Farm Machinery and Power Engineering, \\ FAE, IGKV, Raipur, Chhattisgarh, India \\ ${ }^{3}$ Department of Farm Machinery and Power Engineering, \\ SK CARS, IGKV, Raipur, Chhattisgarh, India \\ *Corresponding author
}

\section{Keywords}

Sugarcane, Height of cut, Effective field capacity and harvesting method

Article Info

Accepted:

12 March 2020

Available Online:

10 April 2020

\section{A B S T R A C T}

Small engine operated sugarcane harvester was tested under the field conditions. The performance evaluation of the small engine operated sugarcane harvester was compared with the traditional method of harvesting. The Small engine operated sugarcane harvester has effective width $100 \mathrm{~cm}$. It was found that $0.1005 \mathrm{ha} / \mathrm{h}$ average effective field capacity at operating speed of $1 \mathrm{~km} / \mathrm{hr}$ and 79.42 per cent field efficiency of sugarcane harvester with minimum labour requirements (5 man-h/ha) as compared to the traditional method of harvesting and we also found that harvesting cost with sugarcane harvester was Rs/ha 3043.50 than that of traditional method $10500 \mathrm{R} / \mathrm{ha}$, sugarcane harvester was found more economical.

\section{Introduction}

In India agriculture is facing serious challenges like scarcity of agricultural labour, not only in peak working seasons but also in normal time. This is mainly for increased nonfarm job opportunities having higher wage, migration of labour force to cities and low status of agricultural labours in the society (Jain et al., 2013).
In manual harvesting to cut one acre of sugarcane 15-16 labours are required they take 3 days to cut one acre. By using this machine problem of the labour crises can be reduced.

Comparing with manual harvesting only $18 \%$ of labours are required, it makes the process faster hence reduces most of the harvesting time and labour required to operate the 
machine is also less. This machine is helpful for both small and big farmers (Ratod et al., 2013).

Kiatiwait et al., (1992) developed a selphpropelled walking type sugarcane harvesterwindrower in Thailand. The machine is a one row single-axle walking-behind-type. It works on the principle of impact cutting by knife blades. As the machine moves forward along the row, the cluster of cane stalks is guided from the divider by a two sets of lugged chains and a spring loaded guide frame. At the narrowest point of guided path, the canes are cut by blades of the base cutter, revolving at peripheral speed approximately $42 \mathrm{~m} / \mathrm{s}$. A pair of solid rubber-gage tractor wheels mounted in the front part of the machine prevents the base cutter blade from striking the ground and control the height of cut. The machine type is 4GZ-9 whole stalk harvester, mounted on 11-14.7 kW hand tractor. Its productivity is $0.1-0.15 \mathrm{ha} / \mathrm{h}$, and it is adapted to row spacing $\geq 1.0 \mathrm{~m}$. shifting a lock-pin along the shaft to make adjustment for various spacing along the adjacent rows.

Salassi et al., (1996) compared that the performance ratings for a single-row wholestalk harvester and a double-row whole-stalk harvester, a single-row chopper harvester, a loader (combine harvester), and a transloader (whole-stalk harvester). For a whole-stalk harvester, the per hour cost of a single-row machine was $35 \%$ less than that of the double row machine. However, per acre cost was $69 \%$ more expensive because the field capacity (acres/h) of a single row harvester was $61 \%$ less than a double-row harvester. Per hour cost for a single row chopper harvester was even higher than a double-row whole-stalk harvester because of more work load and energy consumption.

Moontree et al., (2012) developed sugarcane harvester using small engine in order to focus on its appropriateness in sugarcane farming for farmers who are encountering problems of labor shortage and sugar factories lack sugar cane for producing sugar. It is operated by $180 \mathrm{hp}(134.28 \mathrm{~kW})$ at $2500 \mathrm{rpm}$. Sugarcane was harvested at 12 months after planting with an average-stalk length of $1.8 \mathrm{~m}$, and average-stalk diameter of $0.0254 \mathrm{~m}$, each clump consisted of 8 to 12 stalks, the distance of each sugarcane row was $1.20 \mathrm{~m}$. The sugarcane harvester using small engine can perform at an average speed of $1109.73 \mathrm{~m}^{2} /$ hwith fuel consumption of 20.03 $1 / \mathrm{h}$ and at a mobile speed of $0.25 \mathrm{~km} / \mathrm{h}$. The percentage of sugarcane-cut stalks is $100 \%$.

Jain et al., (2013) designed and fabricated small scale Sugarcane harvesting machine which on testing in the field it is found that the front wheels are struck in mud, due to that the machine was not moving. The machine has a capacity to cut 3.75 ton of sugarcane per hour. Comparing with manual harvesting 50\% of harvesting time and $60 \%$ of labors are reduced (in manual sugarcane harvesting 1516 labors are required).The cost of harvesting is reduced by $34 \%$ when compare to manual harvesting. When comparing with the large scale, though the harvesting time and fuel consumption is less in large scale, but the cost machine is very high (1.85 crore) and the cost of the small scale machine is Rs. 30000/ So it will be helpful to our farmer. By comparing with manual harvesting, Rs.10,000/ for an acre can be saved by small scale harvesting machine.

Ranveer Tambuskar (2015) design and developed, Sugarcane harvesting by a machine has a more capacity to cut the sugarcane faster compared to the manual one. Hence, need of using sugarcane harvester in India is necessary for faster rate of production of sugarcane products as well as harvesters take less time to cut the cane and cuts cane in smaller parts so that it becomes easy to 
transport with larger amount of quantity in one trolley. These Cutting machine has conveying and collecting methodology of a sugarcane harvester as an attachment to the tractor which takes the power from tractor only through its for sugarcane harvesting to reduce farmer's effort and to increase production of agricultural products of sugarcane harvester at the lower cost which can be affordable to Indian farmers or a group of farmers. The cost of an attachments goes up to Rs.35000/.

\section{Materials and Methods}

In order to test the performance of sugarcane harvester for harvesting of the sugarcane crop, it was tested in the farmer's field near the Bhoramdev Cooperative Sugar Factory in Ramhepur, Kawardha. Measurements of the field conditions were row to row spacing plant to plant spacing and field capacity, field efficiency, labour requirement, cost of operation, height of cut and quality of work. The performance of the sugarcane harvester was also compared with manual harvesting by Gadasa and local harvesting equipment.

\section{Row to row spacing}

The row spacing at the farmers' fields varied from 90 to $150 \mathrm{~cm}$. The row spacing is wider $(>1.2 \mathrm{~m})$ where mechanized cultivation was practiced. Traditional practice consist of closer row spacing of 75 to $90 \mathrm{~cm}$ in areas where harvesting was done manually. In order to accommodate mechanical harvesters, farmers have adopted wider row spacing of 120 to $150 \mathrm{~cm}$.

\section{Number of millable canes}

The study of the number of plants in the field and the distribution of stalks along the row were required for harvester. The number of canes at the time of harvest in a meter length of a row was an important factor in deciding the capacity of the machine.

\section{Effective working width}

For determining average Effective working width of the machine at field, three runs were taken. The measurement of the cumulative width of cut for consecutively three test runs was measured at three places selected at random during each test.

\section{Theoretical field capacity}

Theoretical field capacity of machine is the rate of field coverage that would be obtained considering the machine was performing its function at $100 \%$ of the time at the rated speed and always covered $100 \%$ of its rated width.

$$
\mathrm{TFC}=\frac{\mathrm{w} \times \mathrm{s}}{10}-
$$

Where,

TFC $=$ Theoretical field capacity, ha/h

$\mathrm{s}=$ Speed of travel, $\mathrm{km} / \mathrm{h}$

$\mathrm{w}=$ Rated width of machine, $\mathrm{m}$

\section{Effective field capacity}

The Effective field capacity is the actual rate of coverage by the machine, based upon the total field time. The machine was operated with a fixed speed for continuous field work for a fixed time and the area covered during the period was measured to determine the average output per hour.

$\mathrm{EFC}=\frac{\text { Area covered }, \text { ha }}{\text { Time taken to cover the test area, ha }}--(2)$

\section{Field efficiency}

The term field efficiency is used to describe the efficiency of the machine in operation. It is the ratio of effective field capacity to the 
theoretical field capacity expressed as per cent.

ieldefficiency $(\%)=\frac{\text { Effective field capacity }}{\text { Theoritical field capacity }} \times 100$

\section{Height of cut}

For determining the average height of cut of the plants was measured at twenty equidistant places in the direction of travel.

\section{Results and Discussion}

In order to test the performance of small engine operated sugarcane harvester for harvesting of the sugarcane crop, it was tested in the farmer's field near the Bhoramdev Cooperative Sugar Factory in Ramhepur, Kawardha. The row to row and plant to plant spacing was found 90 to $150 \mathrm{~cm}$ and 40 to 45 $\mathrm{cm}$ respectively. The effective width of harvester has $100 \mathrm{~cm}$ and field capacity 0.1005 ha/hr with 5 man-h/ha, at the operating speeds of $1 \mathrm{~km} / \mathrm{hr}$. The average field efficiency of the harvester was found as $79.47 \%$ (Fig. 1-6 and Table 1-3).

The effective field capacity of the harvest sugarcane crop was compared with the harvesting by local Gadasa (plain). Reveals that maximum average effective field capacity $0.1005 \mathrm{ha} / \mathrm{hr}$ was found with the small engine sugarcane harvester followed by the Gadasa $(0.0168 \mathrm{ha} / \mathrm{hr})$ and local cutting equipment $(0.0134 \mathrm{ha} / \mathrm{hr})$.Comparatively the developed cane harvester found economical (harvesting cost Rs/ha 3043.50) than that of traditional (Rs/ha 10500 to 11200). It was also found that millable cane per meter length and height of cut was 25 to 40 and 4 to $6 \mathrm{~cm}$ respectively.

\section{Row spacing}

The row spacing at the farmers fields varied from 60 to $150 \mathrm{~cm}$. But the cost of seed cane, difficulties in carrying out the agricultural Closer row spacing of 75 to $100 \mathrm{~cm}$ was common in these areas. The row spacing was wider $(>1.2 \mathrm{~m})$ where mechanized cultivation was practiced.

Traditional practice consist of closer row spacing of 60 to $90 \mathrm{~cm}$ in areas where harvesting was done manually. In order to accommodate mechanical harvesters, farmers have adopted wider row spacing of 120 to $150 \mathrm{~cm}$. Variety wise row to row and plant to plant spacing are given below.

\section{Number of millable canes}

The number of millable canes along the ridge at the time of harvest was observed in three fields as mentioned above. It was observed that, the number of canes per metre length of the ridge was varied from field to field. Among the three fields, showed that the maximum number of 20 canes per metre. The other two fields the number of plants per metre length was much lesser.

\section{Effective field capacity}

The sugarcane harvester was tested under the various speeds of forward motion ranging from $0.972 \mathrm{~km} / \mathrm{h}$ as minimum to $1.05 \mathrm{~km} / \mathrm{h}$ as maximum. The minimum field capacity obtained as $0.126 \mathrm{ha} / \mathrm{h}$ at the lowest forward motion whereas the maximum forward speed $1.05 \mathrm{~km} / \mathrm{h}$ obtained at full throttle of the small engine operated sugarcane harvester showed the highest field capacity as $0.105 \mathrm{ha} / \mathrm{h}$.

\section{Field efficiency}

The field efficiency obtained at the different speed of the light weight engine operated sugarcane harvester for sugarcane crop harvesting. The average field efficiency of the harvester was found as 79.47 per cent at the different speeds of operation. It was due to the increased effective field capacity as compared to the theoretical field capacity of the harvester. 
Table.1 Row to row and plant to plant spacing

\begin{tabular}{|c|c|c|c|}
\hline S.No. & Variety & Row to row spacing $(\mathbf{c m})$ & Plant to plant spacing $(\mathbf{c m})$ \\
\hline $\mathbf{1}$ & $\begin{array}{c}\text { Co-80036 } \\
\text { (Rasgulla) }\end{array}$ & 70 to 100 & 40 to 45 \\
\hline $\mathbf{2}$ & Co-86032 & 120 to 135 & 65 to 75 \\
\hline $\mathbf{3}$ & $\begin{array}{c}\text { COVSI- } \\
9805\end{array}$ & 130 to 135 & 70 to 80 \\
\hline $\mathbf{4}$ & CO-8014 & 50 to 60 & 55 to 60 \\
\hline $\mathbf{5}$ & COM - & 90 to 100 & 60 to 65 \\
\hline & 0265 & & \\
\hline
\end{tabular}

Table.2 Recorded data during harvesting time.(Co-80036)

\begin{tabular}{|c|c|c|c|}
\hline Observation & Length of cane, cm & Diameter of cane, cm & Height of cut, cm \\
\hline Average & 228 & 2.83 & 4.25 \\
\hline Maximum & 300 & 3.5 & 6 \\
\hline Minimum & 160 & 2.35 & 3 \\
\hline S.D $(\sigma)$ & 50.01 & 0.36 & 0.92 \\
\hline
\end{tabular}

Table.3 Field performance of small engine operated sugarcane harvester

\begin{tabular}{|c|c|c|c|c|c|c|c|c|}
\hline $\begin{array}{c}\text { Particu } \\
\text { lar }\end{array}$ & $\begin{array}{c}\text { Speed, } \\
\mathbf{k m} / \mathbf{h}\end{array}$ & $\begin{array}{c}\text { AFC, } \\
\mathbf{h a} / \mathbf{h}\end{array}$ & $\begin{array}{c}\text { TFC, } \\
\mathbf{h a} / \mathbf{h}\end{array}$ & $\begin{array}{c}\text { Time req., } \\
\mathbf{h}\end{array}$ & $\begin{array}{c}\text { Efficienc } \\
\mathbf{y \%}\end{array}$ & $\begin{array}{c}\text { Losses, } \\
\mathbf{\%}\end{array}$ & $\begin{array}{c}\text { Fuel } \\
\text { consumption, l/h }\end{array}$ & $\begin{array}{c}\text { Labour } \\
\text { req. num. }\end{array}$ \\
\hline Ave. & 1.00 & 0.100 & 0.125 & 0.19 & 79.02 & 2.69 & 2.65 & 5 \\
\hline Max & 1.05 & 0.105 & 0.131 & 0.20 & 80.00 & 3.00 & 2.75 & 5 \\
\hline Min & 0.97 & 0.097 & 0.121 & 0.18 & 76.37 & 2.50 & 2.50 & 5 \\
\hline S.D & 0.03 & 0.003 & 0.0032 & 0.005 & 1.44 & 0.12 & 0.075 & 0 \\
\hline
\end{tabular}

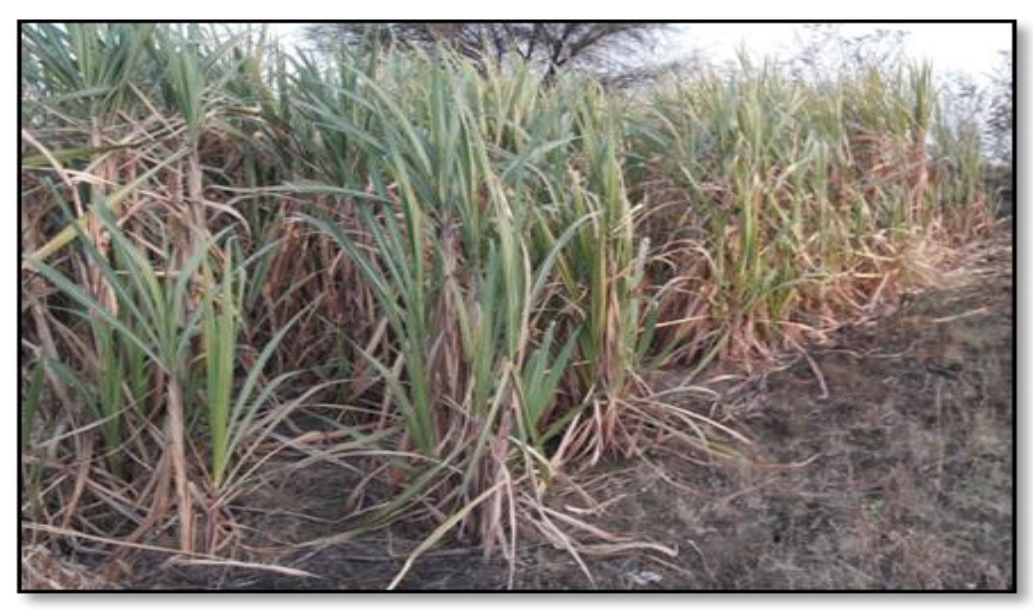

Fig.1 Sugarcane field 


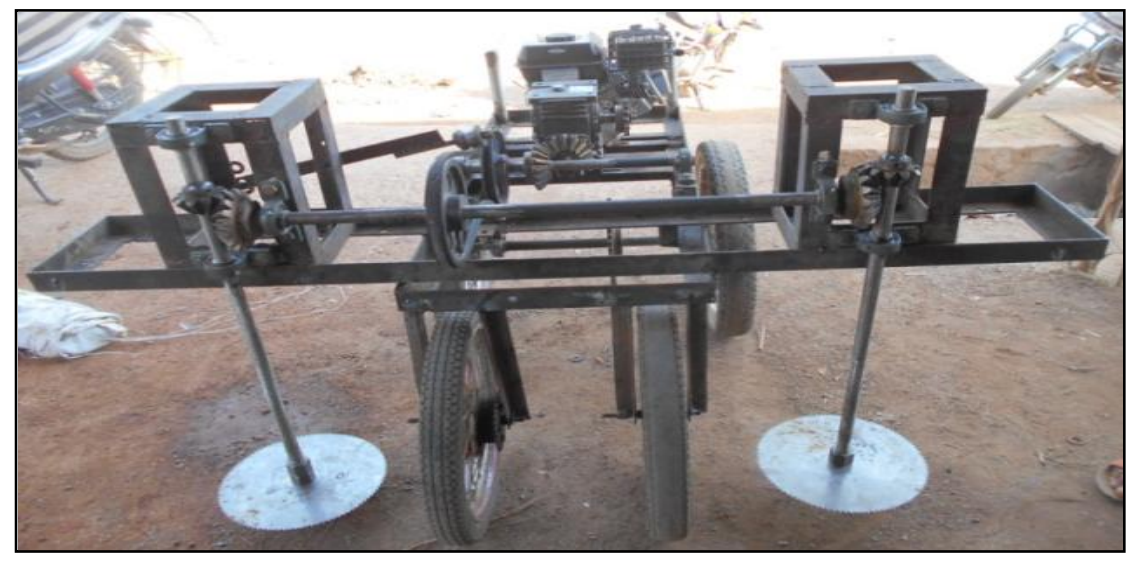

Fig.2 Small engine operated sugarcane harvester

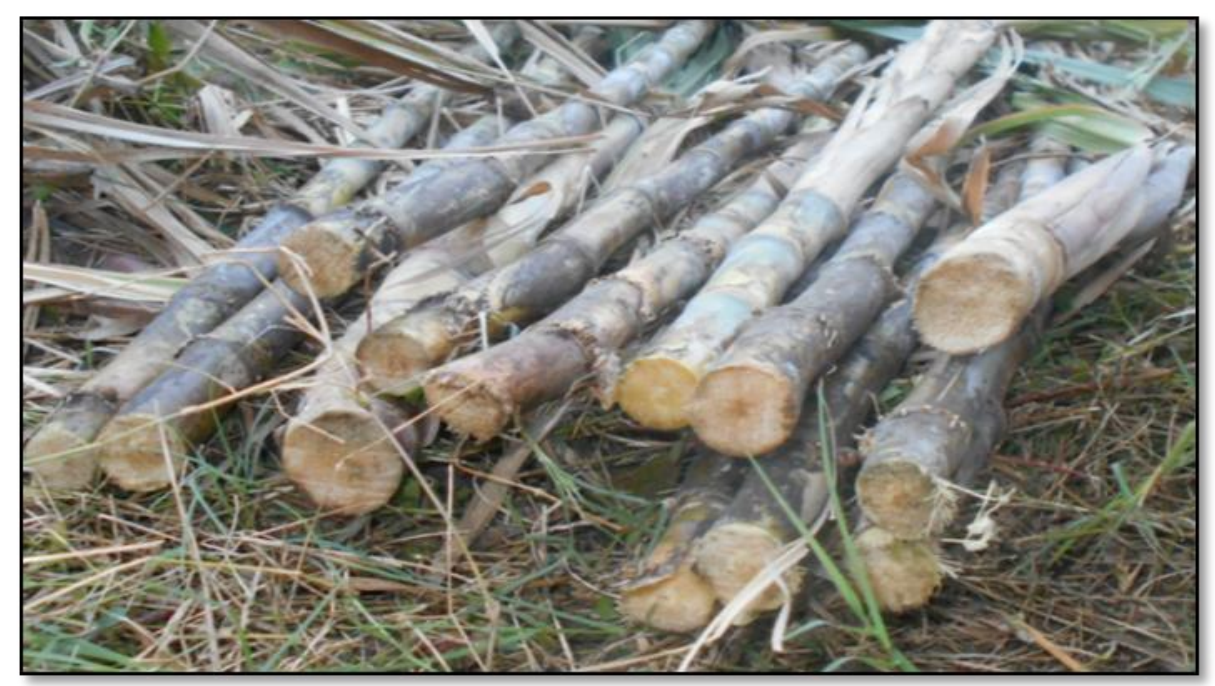

Fig.3 Cutting quality

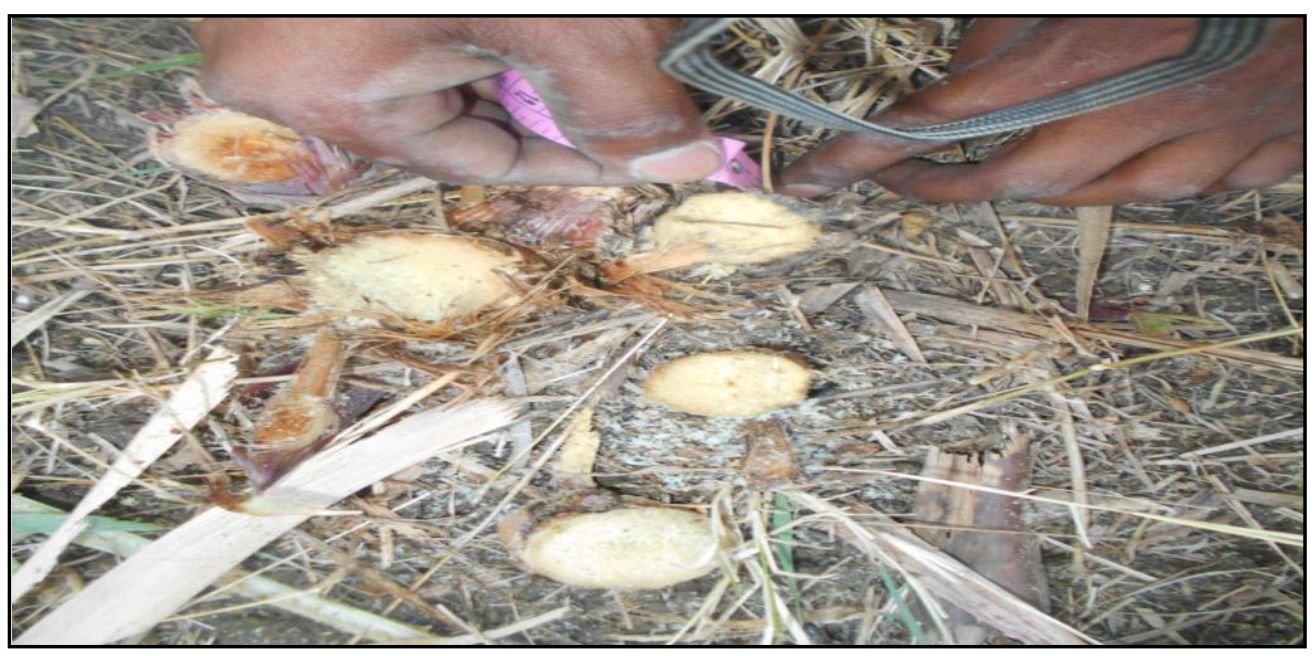

Fig.4 After harvesting left the swath 


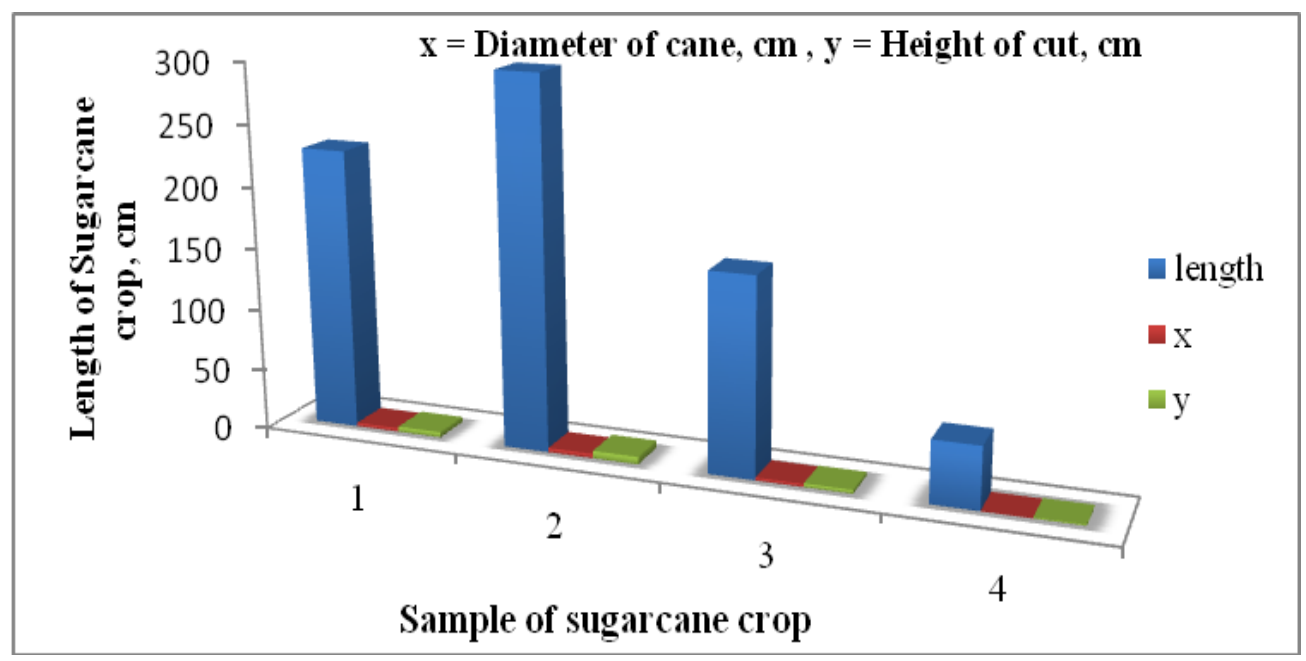

Fig.5 Length, diameter and cutting height of harvested crop

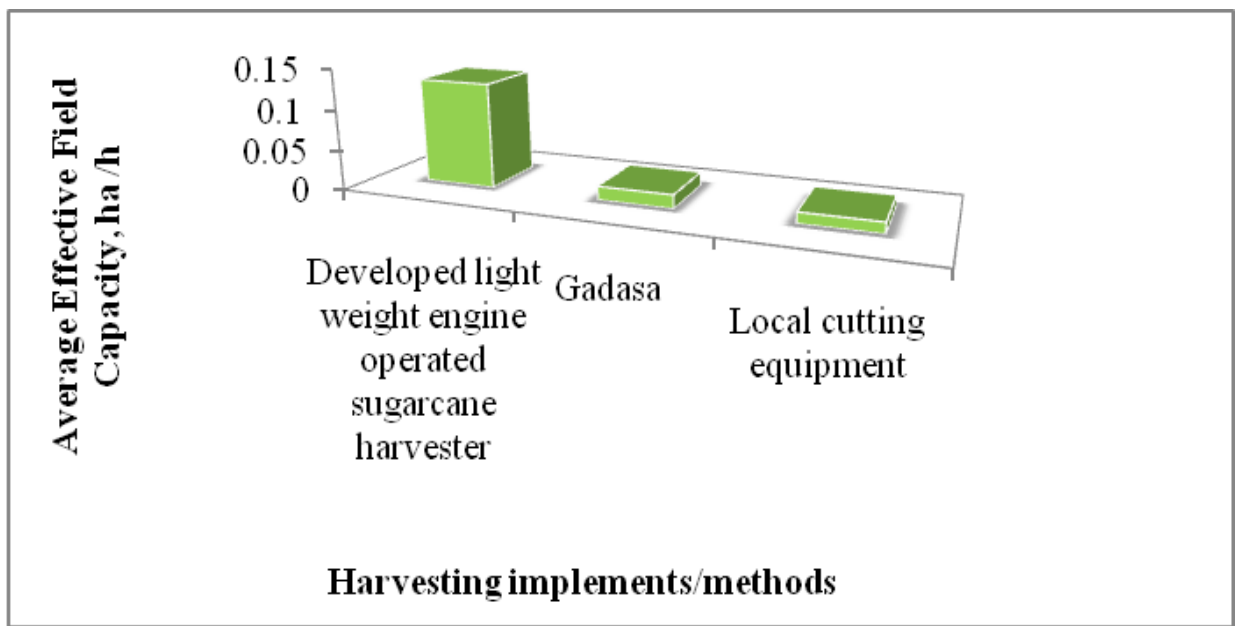

Fig.6 Compression of field capacity by different harvesting method

The harvester performed satisfactory. It was found suitable for harvesting sugarcane crop. It gave satisfactory level of field capacity (0.1005 ha/h) harvesting losses and cost of operation. Following conclusion could be inferred.

The small engine operated sugarcane harvester has width of $100 \mathrm{~cm}$.

It was average forward speed recommended for $1.00 \mathrm{~km} / \mathrm{h}$ to harvest the sugarcane crop.

The performance of small engine operated sugarcane harvester was found satisfactory, It gave field capacity
$0.1005 \mathrm{ha} / \mathrm{h}$ with $5 \mathrm{man}-\mathrm{h} / \mathrm{ha}$.

Comparatively the small engine operated sugarcane harvester found economical (harvesting cost Rs/ha 3043.50) than that of traditional (Rs/ha 10500 to 11200).

It was found height of cut 4 to $6 \mathrm{~cm}$.

\section{References}

Anonymous. 2010. Crop growing manual of sugarcane. Netafim ACS, Israel. http:// www.sugarcanecrops.com

Fuelling, T. 1999. Harvesting quality cane. Proceedings of Australian Society of 
Sugar Cane Tech., 21: 28-32.

Jain, J., Karne, S., Ratod, S., Vinay, N., Thotad and Kiran, P. 2013. Design and fabrication of small scale sugarcane harvesting machine., 2 (3) 2278-0149.

Kiatiwait T., Nuntasukon, S., Sukari, G. and Sarntoonpituk. D. 1992. Testing and Modifying of a walking type sugarcane harvester. Ag. Eng Dev. Dept of Agric., Bangken, Bangkok. Thailand final report.

Moontree, T., Rittidech, S. and Bubphachot, B. 2012. Development of sugarcane harvester using small engine in
Northeast Thailand, International Journal of Physical Sciences., 7(44): 5510-5917

Ranveer, A. and Tambuskar, D. P. 2015. Design and analysis of attachment of sugarcane harvester for a tractor. International journal of engineering sciences and research technology., 4(8): 2277-9655

Salassi, M. E. and Champagne, L. P. 1996. Estimated costs of soldier and combine sugarcane harvesting systems in Louisiana. D.A.E., 703: 59-6.

\section{How to cite this article:}

Md. Tahsin Ashraf, R. K. Naik and Roy, D. K. 2020. Performance Evaluation of Small Engine Operated Sugarcane Harvester. Int.J.Curr.Microbiol.App.Sci. 9(04): 1454-1463. doi: https://doi.org/10.20546/ijcmas.2020.904.171 